\title{
EVALUATION OF AUB AND ITS RELATION WITH SIZE OF UTERUS AND DEMOGRAPHIC VARIABLES AS ASSESSED BY SALINE INFUSION ULTRASONOGRAPHY, HYSTEROSCOPY AND HISTOPATHOLOGY OF ENDOMETRIUM
}

\author{
Neelam Tejwani ${ }^{1}$, Rahul Padval' ${ }^{2}$ P. K. Roy ${ }^{3}$ \\ ${ }^{1}$ Associate Professor, Department of Obstetrics and Gynaecology, R. D. Gardi Medical College, Ujjain. \\ ${ }^{2}$ Consulting Gynaecologist, Department of Obstetrics and Gynaecology, Dahod District Hospital. \\ 3Professor, Department of Obstetrics and Gynaecology, R. D. Gardi Medical College, Ujjain.
}

\begin{abstract}
BACKGROUND
ABSTRACT

Menorrhagia is defined as menstruation at regular interval but with excessive blood and/or duration. Clinically menorrhagia is total blood loss exceeding $80 \mathrm{~mL} / \mathrm{cycle}$ and/or menses lasting longer than 7 days. It may be primary and secondary. Primary is popularly called dysfunctional uterine bleeding (DUB). About $5 \%$ of patients consult family physician for menorrhagia and $12 \%$ of all gynaecological references are for menorrhagia. As per Federation of International Gynaecologist and Obstetricians (FIGO) aetiological classification (2006), there are mainly 9 categories which are arranged according to the acronym PALM - COEIN (Pronounced Palm Koin) (PALM - Structural, COEIN - non-structural): Polyp, adenomyosis, leiomyoma, malignancy, coagulopathy, ovulatory dysfunction, endometrial, iatrogenic and not yet classified.[1]
\end{abstract}

Aim - To know the uterus size that is mostly associated with DUB.

\section{MATERIALS AND METHODS}

A prospective observational study on 97 women attending gynaecological outpatient department (OPD) in R.D. Gardi Medical College between 01-09-2011 to 01-03-2013 was done. Complete clinical and physical examination with ultrasound (USG), hysteroscopy and dilatation and curettage (D\&C) followed by histopathology of the material was done.

\section{RESULTS}

Variables include demographic variables e.g. age, parity, occupation, geographic location, clinical presentation of patients, duration of complaints and on clinical examination, size of uterus and type of complaints.

\section{CONCLUSION}

Most commonly abnormal uterine bleeding (AUB) was associated with uterus of size 6 to 8 weeks. The pathology responsible may be endometritis, adenomyosis, leiomyoma, ovarian cyst, hormonal imbalance, iatrogenic, polyp. The bigger size uterus may cause pressure symptoms more commonly and not the AUB.

\section{KEYWORDS}

Size of Uterus, AUB, Hysteroscopy, Sonography.

HOW TO CITE THIS ARTICLE: Tejwani N, Padval R, Roy PK. Evaluation of AUB and its relation with size of uterus and demographic variables as assessed by saline infusion ultrasonography, hysteroscopy and histopathology of endometrium. J. Evolution Med. Dent. Sci. 2017;6(91):6410-6413, DOI: 10.14260/jemds/2017/1394

\section{BACKGROUND}

Variation from normal cyclical pattern in the perimenopausal age may be due to physiological hormonal changes on one hand or may be due to neoplastic changes either benign or malignant. Therefore, accurate diagnosis of causative factor of AUB is of almost importance so that appropriate management can be established. Sometimes big fibroids of size 10-14 also don't cause menorrhagia but only pressure symptoms, most of the uteruses causing AUB are slightly of bigger size, but correct diagnosis of AUB is important to prevent unnecessary hysterectomy. Malignant part if present cannot be managed conservatively but hormonal imbalance or small submucous fibroid or polyp, endometrial

'Financial or Other Competing Interest': None.

Submission 18-10-2017, Peer Review 12-11-2017,

Acceptance 17-11-2017, Published 27-11-2017.

Corresponding Author:

Dr. P. K. Roy,

Professor,

Department of Obstetrics and Gynaecology,

R. D. Gardi Medical College, Ujjain, M. P.

E-mail: colpkroy@gmail.com

DOI: $10.14260 /$ jemds $/ 2017 / 1394$

\section{(c) (i) $\$$}

hyperplasia which can be diagnosed as well as treated effectively by hysteroscopy are very well managed by hysteroscopy if timely done. Hysteroscopy combined with histological examination is the new gold standard for evaluating a case of AUB.

\section{Aims and Objectives}

To formulate a plan for evaluation of cases of AUB and relation between size of uterus, bleeding patterns and demographic variables like age, parity, duration of complaints, geographical location clinical presentation and type of complaints.

\section{MATERIALS AND METHODS}

This was a prospective observational study conducted on 97 women with history of menorrhagia presenting to Gynaecological OPD and wards of Department of Obstetrics and Gynaecology, R. D. Gardi Medical College. The study was done between 01-09-2011 to 01-03-2013, all patients underwent thorough physical examination and detailed history including routine investigations. All those subjects who fulfilled the eligibility criteria were subjected to clinical examination, saline infusion ultrasonography, hysteroscopy 
and histopathological examination. The patients were included in the trial after due consideration of inclusion and exclusion criteria. A detailed history of the patients was taken with special reference to-

- Chief complaint, which included history of irregular periods.

- $\quad$ History of AUB -

- $\quad$ Cycle length.

- Amount of bleeding.

- Duration of bleeding.

- Menstrual history - Cycles/Frequency/Dysmenorrhoea.

- Obstetric history.

- Past surgical history.

- Contraception history.

- Drug intake.

- Treatment history.

All women underwent a general physical examination and systemic examination and gynaecological examination. Routine blood investigations were done for Haemoglobin estimation, also platelet count, total leucocyte count (TLC), differential leucocyte count (DLC), Blood grouping and $\mathrm{Rh}$ typing, Blood sugar, HIV, HBsAg, VDRL screening and urine routine examination were done. Abdominal and vaginal sonography was done to note uterus (size, position, endometrial thickness), ovaries (size, follicular development), adnexa and Pouch of Douglas. Saline infusion sonography was done by instilling normal saline into Foley catheter No.8. TVS probe $8-13 \mathrm{MHz}$ was attached with LOGIQ P6 model of GE ultrasonography machine. 50 hysteroscopies were done because of AUB (abnormal uterine bleeding).

All women underwent diagnostic hysteroscopy by 0 \& 30 hysteroscope for endometrial lining, submucous fibroid and endometrial polyp and any other structural abnormality.

Results variable include demographic variables e.g. Age, parity, occupation, geographic location, clinical presentation of patients, duration of complaints and on clinical examination, size of uterus and type of complaints.

Results of SIS and Hysteroscopy and histopathology were included to compare distribution of patients according to type of complaints and size of uterus compared to detect most notorious size of uterus causing DUB. Data so collected was entered simultaneously into "statistical package for social scientists" (SPSS) software version, 23.0 and coded appropriately. Advice of statistician was taken. Chi square test was used for significant correlation of data. Data were entered in MS Excel spread sheet and analysis was done using "statistical package for social scientists" (SPSS) software version, 23.0. $P$ value $<0.05$ is considered significant.

\section{Inclusion Criteria}

Women aged between 18-50 years, married, with history of menorrhagia.

\section{Exclusion Criteria}

Unwilling women, unmarried, active cervical and uterine infection, or any Pelvic malignancy.

\section{Ethical Aspect}

Patients were explained about the study and informed consent was taken. The proposal was cleared by the institutional ethical committee.

\section{Review of Literature}

When viewed from a perspective of ovarian function, the menstrual cycle can be divided into pre-ovulatory follicular phase and post-ovulatory luteal phase. Corresponding phases in the endometrium are termed as proliferative and secretory phases. In normal menstruation, one half to three quarters of the menstrual discharge is blood, the rest being fragments of endometrial tissue and mucus. Menstrual blood does not clot and consists of aggregation of endometrial tissue, red cells, degenerated platelets and fibrin. ${ }^{[2]}$

\section{Characteristics of a Normal Menstrual Cycle[3],[4]}

\begin{tabular}{|c|c|c|c|}
\hline & Average & Range & Abnormal \\
\hline Cycle length & 28 days & $21-35$ days & $<21->35$ days \\
\hline Duration & 4 days & $1-8$ days & $>8$ days \\
\hline Blood loss & $35 \mathrm{~mL}$ & $20-80 \mathrm{~mL}$ & $>80 \mathrm{~mL}$ \\
\hline
\end{tabular}

\section{AUB and Terminologies used to describe AUB}

It is defined as an excessive, erratic or irregular bleeding in the presence or absence of intracavitary or uterine pathology. It may be associated with structural or systemic abnormalities. ${ }^{[5]}$

The term Dysfunctional Uterine Bleeding (DUB), which was previously used as a diagnosis when there was no systemic or locally definable structural cause for AUB, is not included in the FIGO classification system of AUB and should be abandoned, per the agreement process.[6],[7]

\section{Terminologies used to describe AUB[8]}

\begin{tabular}{|c|c|c|c|}
\hline \multicolumn{4}{|c|}{ Abnormal Menses Terminology } \\
\hline Term & Interval & Duration & Amount \\
\hline Menorrhagia & Regular & Prolonged & Excessive \\
\hline Metrorrhagia & Irregular & Prolonged & Normal \\
\hline Menometrorrhagia & Irregular & Prolonged & Excessive \\
\hline Polymenorrhoea & $\begin{array}{c}\text { Regular (but } \\
<21 \text { days) }\end{array}$ & Normal & Excessive \\
\hline Hypomenorrhoea & Regular & Normal or less & Less \\
\hline Oligomenorrhoea & $\begin{array}{c}\text { Infrequent or } \\
\text { irregular }\end{array}$ & Variable & Scanty \\
\hline Amenorrhoea & Absent & $\begin{array}{c}\text { No menses for } \\
90 \text { days }\end{array}$ & Absent \\
\hline
\end{tabular}

\section{Definition of Menorrhagia on Broader Aspect}

Menorrhagia is defined as menstruation periods at regular cycle but with excessive flow which may last more than 7 days. Menorrhagia can cause menstrual bleeding of more than $80 \mathrm{~mL}$ in each cycle.[9]

Menorrhagia is largely responsible for iron deficiency and iron deficiency anaemia both of which have negative effects on women health. These are major reasons for women consulting gynaecology departments, being hospitalised, and having operation. Several studies mention the negative effects of menorrhagia in women.[10],[11],[12],[13]

Size of uterus may increase due to adenomyosis, the relation between adenomyosis and AUB is unclear. Incidence of adenomyosis vary widely from 5-70\%.[14] The histopathological criteria for diagnosis of adenomyosis is based on histopathological evaluation of depth of endometrial tissue beneath endometrial myometrial interface as determined by hysterectomy.[15] The requirement to diagnose adenomyosis safely from specimen obtained by 
hysterectomy has united value in chemical classification system. These exist in both sonographic[16] and MRI[17],[18] based diagnostic criteria for adenomyosis.

The second most common reason for increase in uterine size is leiomyoma, benign fibromuscular tumour of the myometrium. Like polyp and adenomyosis, leiomyomatosis is asymptomatic and frequently their presence is not the cause of AUB. Submucous fibroid even if small can cause menorrhagia.

Disorder of ovulation may present as a spectrum of menstrual abnormality ranging from amenorrhoea to light and infrequent bleeding to episodes of unpredictable and extremely heavy menstrual bleeding requiring medical or surgical treatment. Some of those manifestations relate to absence of predictable cyclic progesterone production from corpus luteum every 22-35 days but in later reproductive years relate to unusual disturbed ovulation which has been labelled as luteal out of phase event.[19][20] Although most ovulatory disorders include a defined aetiology, many can be traced to endocrinopathies [e.g. Polycystic ovarian disease (PCOD), hypothyroidism, hyperprolactinaemia, mental stress, obesity, anorexia, weight loss, extreme exercise].

When AUB is of typical ovulatory type and no other definite cause can be traced, primary disorder of endometrium is the probable cause. There may exist a primary disorder of mechanism regulating local endometrial haemostasis itself. Indeed high quality evidence has demonstrated deficiency in local production of vasoconstrictors such as endothelin 1 and prostaglandin f2 alpha and/or accelerated lysis of endometrial clot due to excessive production of plasminogen activator,[21-22] in addition to increased local production of substances that promote vasodilatation such as prostaglandin E2 and prostacyclin.[23],[24],[25]

There are several mechanisms (iatrogenic) by which medical intervention or device can cause AUB. These include medicated or inert intrauterine devices and pharmacological agents that directly impact endometrium, interfere with blood coagulation system or influence systemic control of ovulation.

\section{RESULTS}

Distribution of patients according to type of complaints and size of uterus on clinical examination:

Out of 97 patients, 56 patients $(57.74 \%)$ presented with menorrhagia, 27 (27.84\%) had polymenorrhoea, 7 (7.3\%) had metrorrhagia, and 7 (7.3\%) had menometrorrhagia. Out of $56(57.73 \%)$ patients having complaints of menorrhagia, 7 $(12.5 \%)$ had normal size uterus, $45(80.35 \%)$ had uterus of 6 to 8 weeks size, $3(5.3 \%)$ had uterus of 8 to 10 weeks size and only $1(1.7 \%)$ had uterus of size more than 10 weeks. Out of 7 (7.21\%) patients having complaints of metrorrhagia, 2 (28.57\%) had normal size uterus, $5(71.42 \%)$ had uterus of 6 to 8 weeks size and none had uterus of 8 to 10 weeks or more than 10 weeks. Out of 7 (7.21\%) patients having complaints of menometrorrhagia, $3(42.85 \%)$ had normal size uterus, 4 $(57.14 \%)$ had uterus of 6 to 8 weeks size and none had uterus of 8 to 10 weeks or more than 10 wks. Out of $27(27.83 \%)$ patients having complaints of polymenorrhoea, $18(66.66 \%)$ had normal size uterus, $6(22.22 \%)$ had uterus of 6 to 8 weeks size, $2(7.4 \%)$ had uterus of 8 to 10 weeks size and only $1(3.7 \%)$ patient had uterus of size more than 10 weeks.

\begin{tabular}{|c|c|c|c|c|c|}
\hline \multirow{2}{*}{$\begin{array}{c}\text { Type of } \\
\text { Complaints }\end{array}$} & $\mathbf{N = 9 7}$ & \multicolumn{4}{|c|}{ Size of Uterus } \\
\cline { 2 - 6 } & & $\begin{array}{c}\text { Normal } \\
\text { Size }\end{array}$ & $\begin{array}{c}\mathbf{6 - 8} \\
\text { Weeks }\end{array}$ & $\begin{array}{c}\mathbf{8 - 1 0} \\
\text { Weeks }\end{array}$ & $\begin{array}{c}>\mathbf{1 0} \\
\text { Weeks }\end{array}$ \\
\hline $\begin{array}{c}\text { Menorr- } \\
\text { hagia }\end{array}$ & 56 & 7 & 45 & 3 & 1 \\
$(57.73 \%)$ & $(12.5 \%)$ & $(80.35 \%)$ & $(5.3 \%)$ & $(1.7 \%)$ \\
\hline $\begin{array}{c}\text { Metrorr- } \\
\text { hagia }\end{array}$ & 7 & 2 & 5 & 0 & 0 \\
$(7.21 \%)$ & $(28.57 \%)$ & $(71.42 \%)$ & $(0 \%)$ & $(0 \%)$ \\
\hline $\begin{array}{c}\text { Menometr } \\
\text { orrhagia }\end{array}$ & 7 & 3 & 4 & 0 & 0 \\
$(7.21 \%)$ & $(42.85 \%)$ & $(57.14 \%)$ & $(0 \%)$ & $(0 \%)$ \\
\hline $\begin{array}{c}\text { Polymenor } \\
\text {-rhagia }\end{array}$ & $\begin{array}{c}27 \\
(27.83 \%)\end{array}$ & $\begin{array}{c}18 \\
(66.66 \%)\end{array}$ & $\begin{array}{c}6 \\
(22.22 \%)\end{array}$ & $\begin{array}{c}2 \\
(7.4 \%)\end{array}$ & $\begin{array}{c}1 \\
(3.7 \%)\end{array}$ \\
\hline Total & 97 & 30 & 60 & 5 & 2 \\
$(100 \%)$ & $(30.92 \%)$ & $(61.85 \%)$ & $(5.15 \%)$ & $(2.06 \%)$ \\
\hline
\end{tabular}

Table 1. Distribution of Patients According to Type of

Complaint and Size of Uterus on Clinical Examination

Out of 97 patients of AUB, 30 (30.92\%) had normal uterus size, $60(61.85 \%)$ had 6 to 8 weeks size, $5(5.1 \%)$ had 8 to 10 weeks size, while $2(2.06 \%)$ had more than 10 weeks uterus size.

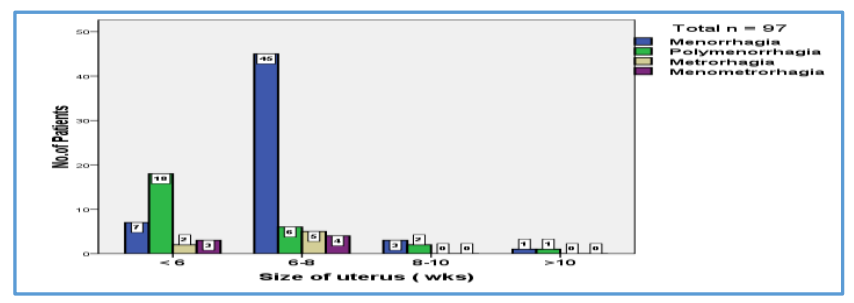

Figure 1: Patients Distribution According to Type of Complaints and Size of Uterus

Majority of patients having complaints of menorrhagia $(n=56)$, had clinically 6 to 8 weeks gravid uterus $(n=45)$. In patients having complaints of polymenorrhoea $(n=27)$, majority of patients had normal size uterus $(n=18)$.

\section{DISCUSSION}

In the present study, $25.77 \%$ of subjects had parity less than two, and $72.16 \%$ of subjects had parity more than two. Thus, parity more than 2 formed bulk of cases i.e. $72.16 \%$ which is significant $\mathrm{p}<0.01$. $38.14 \%$ of subjects were housewives, $55.67 \%$ of subjects were farmers, and $6.19 \%$ were labourers. Thus, $61.86 \%$ of subjects were farmers and labourers and were involved in heavy physical work $(p<0.01)$. So, loss of working hours due to menorrhagia in agricultural country like us has great impact on economy.

\section{Correlation of Bleeding Pattern}

In the present study, when AUB was analysed as per pattern of bleeding, the incidence of menorrhagia was $57.74 \%$, polymenorrhagia was $27.84 \%$, metrorrhagia was $7.3 \%$ and menometrorrhagia was $7.3 \%$. The incidence of menorrhagia of the present study is comparable to other studies.

Majority of subjects with excessive bleeding reported within a year of onset of complaints: $38.1 \%$ of subjects had 4 to 6 months duration, $32 \%$ had 7 to 9 months duration, $14.4 \%$ had 10 to 12 months, $8.2 \%$ had 1 to 3 months, and $7.2 \%$ subjects had more than 12 months duration of complaints.

In the present study analysis of SIS of total $(n=97)$ subjects, $42 \%$ subjects had normal findings, while $28.8 \%$ had polyps, $24.7 \%$ had submucous fibroids, and $4.1 \%$ had 
endometrial hyperplasia which is comparable to other studies.

In the present study analysis of hysteroscopy out of total ( $\mathrm{n}=97$ ) subjects, $44 \%$ had normal findings, while abnormal findings i.e. $23.7 \%$ polyps, $21.6 \%$ submucous fibroid, $5.1 \%$ had endometrial hyperplasia and 1 abnormal finding include placental polyp which on SIS diagnosed submucous fibroid.

\section{CONCLUSION}

- Menorrhagia is more common in reproductive age group of 20-40 years of age with mean age of 36.4 years.

- Menorrhagia is more common in women with parity $\geq$ 2.

- Majority of women seek treatment for menorrhagia within one year of onset of complaint.

- $\quad$ Clinically majority of patients having menorrhagia had 6 - 8 weeks size of uterus, while polymenorrhoea and metrorrhagia had normal size uterus.

\section{REFERENCES}

[1] Hallberg L, Nilsson L. Determination of menstrual blood loss. Scand J Clin Lab Invest 1964;16:244-8.

[2] Neinstein LS. Menstrual problems in adolescents. Med Clin North Am 1990;74(5):1181-203.

[3] Munro MG, Crithcley HO, Broder MS, et al. FIGO classification system (PALM-COEIN) for causes of abnormal uterine bleeding in nongravid women of reproductive age. International Journal of Gynecology and Obstetrics 2011;113(1):3-13.

[4] Daveyda. Dysfunctional uterine bleeding. Dewhurst's text book of Obstetrics and Gynaecology for post graduates. $6^{\text {th }}$ edn. Blackwell Science 1995:590-608.

[5] Goldstein SR, Zeltser I, Horan CK, et al. Ultrasonography-based triage for perimenopausal patients with abnormal uterine bleeding. Am J Obstet Gynec 1997;177(1):102-8.

[6] Chimbira TH, Anderson AB, Turnbull AC. Relation between measured menstrual blood loss and patient's subjective assessment of loss, duration of bleeding, number of sanitary towels used, uterine weight and endometrial surface area. Br J Obstetrics Gynaecology 1980;87(7):603-9.

[7] Schorge JO, Schaffer JI, Halvorson LM, et al. Williams Gynecology. $1^{\text {st }}$ edn. McGraw-Hill Medical Publication 2008:174-92.

[8] Fraser IS, Critchley HO, Munro MG, et al. A process designed to lead to international agreement on terminologies and definitions used to describe abnormalities of menstrual bleeding. Fertil Steril 2007;87(3):466-76.

[9] Fraser IS, Critchley HO, Munro MG, et al. Can we achieve international agreement on terminologies and definitions used to describe abnormalities of menstrual bleeding? Hum Reprod 2007;22(3):635-43.
[10] Paula J, Hillard A. Benign disease of the female reproductive tract. Berek and Novak's Gynecology. $15^{\text {th }}$ edn. Lippincott Williams \& Wilkins 1999: p. 404.

[11] Heavy menstrual bleeding. NICE Clinical Guideline 2007.

[12] Engstrom JL, Rose R, Brill AI, et al. Midwifery care of the woman with menorrhagia. Journal of NurseMidwifery 1999;44(2):89-105.

[13] Kadir RA, Edlund M, von Mackensen S. The impact of menstrual disorders on quality of life in women with inherited bleeding disorders. Haemophilia 2010;16(5):832-9.

[14] Sambrook AM, Cooper K. RCOG guidelines on menorrhagia - time for an update? Current Obstetrics \& Gynaecology 2005;15(6):382-6.

[15] Shankar M, Chi C, Kadir RA. Review of quality of life: menorrhagia in women with or without inherited bleeding disorders. Haemophilia 2008;14(1):15-20.

[16] Dueholm M. Transvaginal ultrasound for diagnosis of adenomyosis: a review. Best Pract Res Clin Obstet Gynaecol 2006;20(4):569-82.

[17] Brosens JJ, de Souza NM, Barker FG, et al. Endovaginal ultrasonography in the diagnosis of adenomyosis uteri: identifying the predictive characteristics. Br J Obstet Gynaecol 1995;102(6):471-4.

[18] Mark AS, Hricak H, Heinrichs LW, et al. Adenomyosis and leiomyoma: differential diagnosis with MR imaging. Radiology 1987;163(2):527-9.

[19] Togashi K, Nishimura K, Itoh K, et al. Adenomyosis: diagnosis with MR imaging. Radiology 1988;166(1 Pt 1):111-4.

[20] Dueholm M, Lundorf E, Hansen ES, et al. Magnetic resonance imaging and transvaginal ultrasonography for the diagnosis of adenomyosis. Fertil Steril 2001;76(3):588-94.

[21] Hale GE, Manconi F, Luscombe G, et al. Quantitative measurements of menstrual blood loss in ovulatory and anovulatory cycles in middle - and latereproductive age and the menopausal. Obstet Gynecol 2010;115(2 Pt 1):249-56.

[22] Gleeson NC. Cyclic changes in endometrial tissue plasminogen activator and plasminogen activator inhibitor type 1 in women with normal menstruation and essential menorrhagia. Am J Obstet Gynecol 1994;171(1):178-83.

[23] Smith SK, Abel MH, Kelly RW, et al. A role for prostacyclin (PGi2) in excessive menstrual bleeding. Lancet 1981;1(8219):522-4.

[24] Smith SK, Abel MH, Kelly RW, et al. Prostaglandin synthesis in the endometrium of women with ovular dysfunctional uterine bleeding. Br J Obstet Gynaecol 1981;88(4):434-42.

[25] Pitsos M, Skurnick J, Heller D. Association of pathologic diagnoses with clinical findings in chronic endometritis. J Reprod Med 2009;54(6):373-7 